
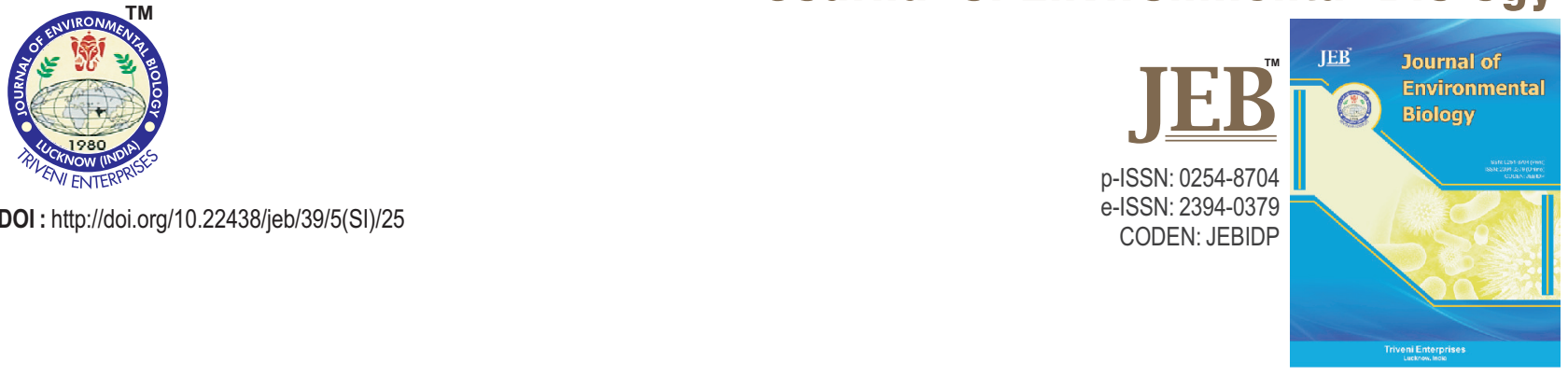

\title{
Antibacterial activity of garlic extracts on fish pathogenic bacteria
}

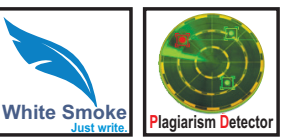

Authors Info

R. Natasya-Ain', N. Eirna-Liza, ${ }^{1,3}$ M.Y. Jasmin ${ }^{1}$ and Murni Karim ${ }^{\star 1,2}$

'Department of Aquaculture, Faculty of Agriculture, Universiti

Putra Malaysia, 43400, Serdang, Selangor, Malaysia

'Laboratory of Marine

Biotechnology, Institute of Bioscience, Universiti Putra Malaysia, Universiti Putra Malaysia, 43400, Serdang, Selangor, Malaysia

${ }^{3}$ University College of Agroscience Malaysia, Alor Gajah, 78000 Malacca, Malaysia

${ }^{*}$ Corresponding Author Email : murnimarlina@upm.edu.my

\section{Key words}

Allicin

Antibacterial activity

Garlic extracts

Marine pathogens

Phytobiotics

\section{Publication Info}

Paper received : 23.05.2017

Revised received : 29.08.2017

Re-revised received : 16.11.2017 Accepted : 28.12.2017

\begin{abstract}
Aim : Aqueous and methanol extracts of Allium sativum (clove and peel) were investigated for their antibacterial properties in in-vitro assay against four marine pathogens, Aeromonas hydrophila, Vibrio anguillarum, Vibrio alginolyticus and Vibrio harveyi.
\end{abstract}

Methodology : Different concentrations of methanol and aqueous garlic extracts were used in different methods including the disc-diffusion, minimal inhibitory concentration (MIC) and minimal bactericidal concentration (MBC) assay.

Results : The aqueous extract of $A$. sativum (clove and peel) had no antibacterial effect against the pathogenic bacteria tested, while the clove extract of methanol showed a strong inhibition activity against pathogens tested. The largest inhibition zone was observed against $A$. hydrophila $(15.3 \pm 0.3)$ and the least

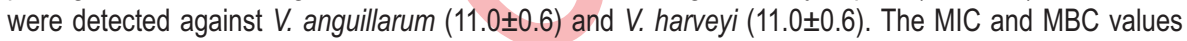
revealed that $A$. hydrophila was inhibited by a supernatant extract of clove at the lowest concentration of 0.6 $\mathrm{mg} \mathrm{ml}^{-1}$, while other pathogens were inhibited at the concentration of 0.8 and $1.0 \mathrm{mg} \mathrm{ml}^{-1}$.

Interpretation : This study suggests that clove extract of $A$. sativum has the potential to be used as a phytobiotics in controlling the growth of marine pathogens.
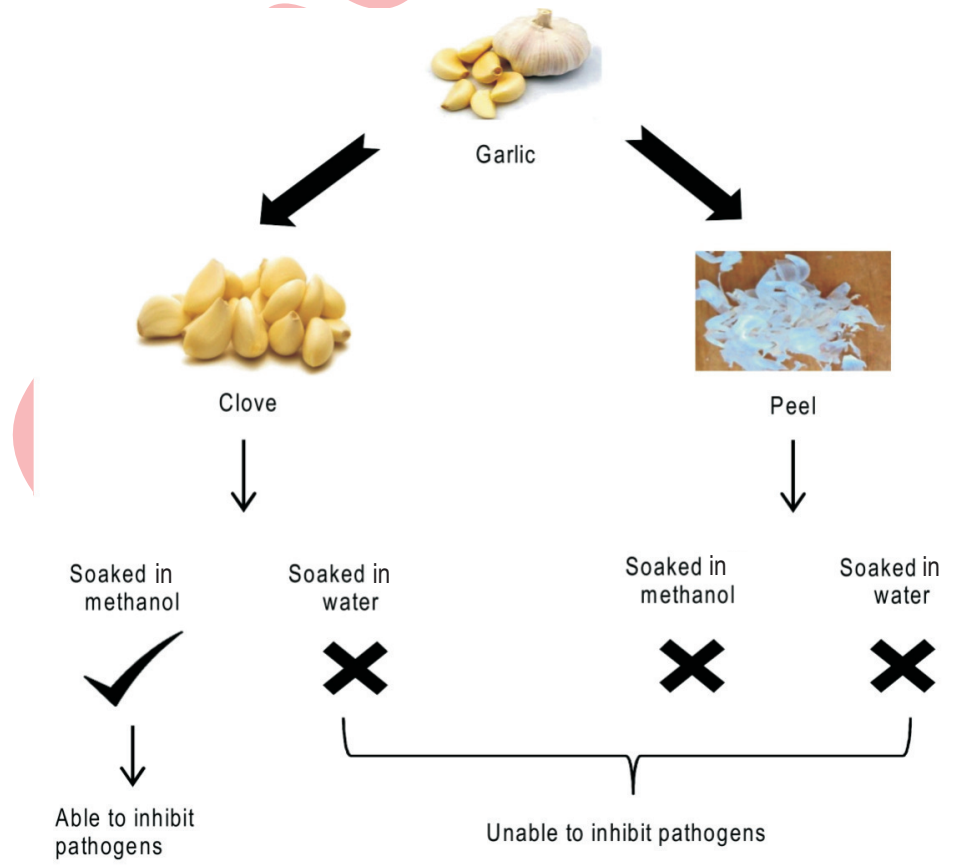

pathogens 


\section{Introduction}

Infectious diseases are one of the main factors contributing to high losses in the aquaculture industry as the demand in this sector increases (Bondad-Reantaso et al., 2005). The awareness of safe food demand has lead to the search of natural products as growth promoters and/or prophylactics in aquatic feeds (Kareem et al., 2016; Sheikhlar et al., 2017).

Phytobiotic is one of the alternatives used in the aquaculture sector. Phytobiotic is defined as natural compounds derived from plants, which can enhance animal productivity once included in the diets. Many plant products such as Aloe vera, onion, ginger, garlic, thyme, neem, peppermint, medlar and rosemary have been used as immunity stimulation and growth promoter in aquaculture (Kolkovski et al., 2011; Hoseinifar et al., 2017). Moreover, they contain beneficial proteins, amino acids, vitamins, lipid, trace elements, and some unknown growth promoting factors that can strengthen metabolism of aquatic animals, enhance the composition of protein and enzymes, and expedite the growth of animals (Yin et al., 2006). Cristea et al. (2012) demonstrated various properties of phytobiotics including enhancing appetites, promoting growth, acting as antioxidants, stimulating the digestive system, being anticarcinogenic or having antiparasitic, antimicrobial or insecticidal activities.

Allium sativum, commonly known as garlic, has been known for centuries for its importance in the dietary role and medicinal properties. Block (1985) revealed that the typical odor and flavor of garlic were attributed to water-soluble organosulfur compounds and some specific oils that had therapeutic and prophylactic effects. This was later supported by Ariga and Seki (2006) who suggested that the extensive variety of dietary and medicinal properties of garlic is due to the compounds of sulfur found in the garlic. These sulphur compounds are also responsible for the characteristic flavour of fresh garlic (Li etal., 2007).

Currently, antibiotics are sometimes applied in aquaculture to control bacterial infections, but their application has led to increased development of drug-resistant bacteria. Moreover, the antibiotic accumulation in aquatic animals and environment are generally unsafe to consumers and the environment (Alderman and Hastings, 1998). A study conducted by Durairaj et al. (2009) showed that foods and consumers can be protected from the risk of pathogenic bacteria by using garlic. Thus, natural products have been considered as an alternative to control bacterial infections in aquaculture. Moreover, CorzoMartinez et al. (2007) stated that garlic helps in controlling the pathogens, especially bacteria and fungi, and increases the well being of aquatic animals. Unfortunately, large quantities of garlic are consumed but the outer layer is treated as waste. Thanikachalam et al. (2010) reported that the outer layer of garlic has bioactive substances that are capable of acting as immunostimulant in fish. Thus, all the parts of garlic (peels and cloves) have their own active compounds. In this study, A. sativum (garlic) was investigated for its antibacterial activity against four major marine pathogens; Aeromonas hydrophila, Vibrio harveyi, Vibrio anguillarum and Vibrio alginolyticus. Different extractants (water and methanol) were used to extract garlic peel and clove, and were used to test their effectiveness against different pathogenic bacteria in fishes.

\section{Materials and Methods}

Preparation of garlic extracts : Garlic was purchased from grocery store in Serdang, Selangor. Two types of extracts were prepared; methanol and aqueous extracts of peels and cloves. The garlic cloves and peels were cleaned, peeled, sliced and oven dried at $70^{\circ} \mathrm{C}$ for $24 \mathrm{hrs}$. Each of the dried samples was grounded into powder using a blender. A $10 \mathrm{~g}$ powder of garlic cloves and garlic peels were soaked in different extracts including $100 \mathrm{ml}$ of distilled water and $10 \%, 20 \%$ and $40 \%$ of methanol, respectively. The flasks were then shaken at $120 \mathrm{rpm}$ and incubated for $72 \mathrm{hrs}$ at room temperature.

The supernatant from each extract (water, $10 \%, 20 \%$ and $40 \%$ of methanol) were collected and labeled as supernatant extract of clove and supernatant extract of peel, respectively. Each of the dried crude extracts was dissolved in $100 \mathrm{mg} \mathrm{ml}^{-1}$ of distilled water as final concentrations. In order to remove the excess residues, the samples were further centrifuged at 10,000 $\mathrm{rpm}$. The previous steps were repeated at $25^{\circ} \mathrm{C}$ for $10 \mathrm{~min}$. The extract solutions were stored at $-20^{\circ} \mathrm{C}$ for further use. These extracts were labeled as crude extract of clove and crude extract of peel. For control, methanol and distilled water were prepared by following the same methods ascribed above and were tested for their antimicrobial properties (Fig. 1).

Pathogenic bacteria strains : Vibrio alginolyticus, V. harveyi, V. anguillarum and $A$. hydrophila were obtained from the Labarotory of Fish Health in the Aquaculture Department, Universiti Putra Malaysia. All the isolates were cultured in Tryptic Soy Agar (TSA) and Tryptic Soy Broth (TSB) at $30^{\circ} \mathrm{C}$ for overnight.

Stagnant Method: Disc-diffusion assay : A $6 \mathrm{~mm}$ diameter paper discs were sterilized and different concentrations of garlic extracts were prepared $\left(1.0 \mathrm{mg} \mathrm{ml}^{-1}, 2.0 \mathrm{mg} \mathrm{ml}^{-1}, 4.0 \mathrm{mg} \mathrm{ml}^{-1}, 6.0\right.$ $\mathrm{mg} \mathrm{ml}^{-1}, 8.0 \mathrm{mg} \mathrm{ml}^{-1}, 10.0 \mathrm{mg} \mathrm{ml}^{-1}$ ). The discs were introduced with $10 \mu \mathrm{l}$ of each garlic extract concentration. The discs were left for few minutes to allow the absorption of the solution.

Next, $10 \mathrm{ml}$ of TSB was used as a medium to inoculate each of the pathogenic bacteria and incubated overnight at $30^{\circ} \mathrm{C}$. The culture was swabbed on the TSA agar using a sterilized cotton swab. Later, the discs that were prepared earlier with different concentrations of each supernatant extracts of clove, supernatant extract of peels, crude extracts of clove and crude extract of peel, were placed on the inoculated TSA. After half an hour of discs application, the plates were incubated at $30^{\circ} \mathrm{C}$ for a period of $24 \mathrm{hrs}$. Meanwhile, the disc that contained only sterile 


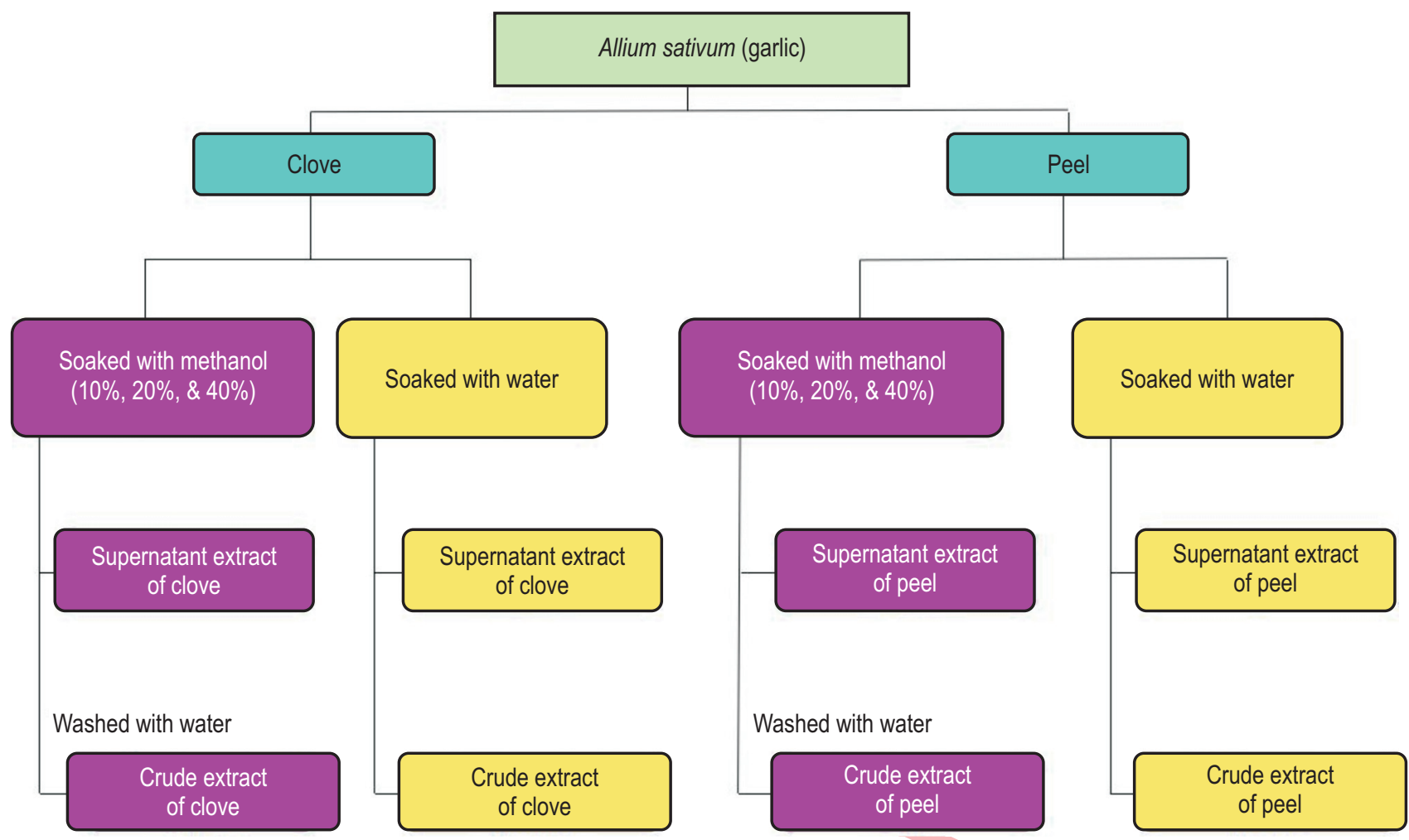

Fig. 1: Extraction of garlic

distilled water and methanol was used as control. Inhibition zone formed was observed on the plate on the next day. The diameter of the inhibition zone was measured and recorded accordingly (Durairaj etal., 2009).

Broth dilution method - Minimum Inhibitory Concentration : The minimum inhibitory concentration (MIC) of the aqueous garlic extract was evaluated by using the broth dilution method with 96 well plates. Pathogenic strains were cultured in TSB. Each cell

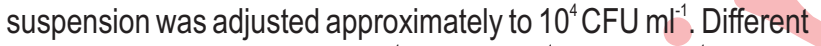
concentrations $\left(1.0,2.0 \mathrm{mg} \mathrm{ml}^{-1}, 4.0 \mathrm{mg} \mathrm{ml}^{-1}, 6.0 \mathrm{mg} \mathrm{ml}^{-1}, 8.0 \mathrm{mg}\right.$ $\left.\mathrm{ml}^{-1}, 10.0 \mathrm{mg} \mathrm{m}^{-1}\right)$ of garlic extracts were pre-incubated with $100 \mu \mathrm{l}$ of pathogen suspension $\left(10^{4} \mathrm{CFU} \mathrm{ml}^{-1}\right)$ in the respective wells. Uninoculated wells that contained TSB, garlic extracts only, and pathogens only were used as controls. The plate was incubated at $30^{\circ} \mathrm{C}$ for 24 and 48 hrs (Durairaj et al., 2009). The minimum inhibitory concentration is defined as the minimum concentration of garlic extract that is able to inhibit the pathogenic bacteria significantly.

Minimum Bactericidal Concentration : Results were evaluated as outlines for MIC by pipetting the medium with a combination of all of the wells onto TSA and TCBS plates. The plates were incubated for 24 to $48 \mathrm{hrs}$ at $30^{\circ} \mathrm{C}$. MBC indicates the concentration at which no microbial growth was formed on the plate.

\section{Results and Discussion}

This study assay demonstrated that supernatant extract of clove showed some antibacterial activities against the pathogenic bacteria tested. Meanwhile, the crude extract of clove, supernatant extract of peel and crude extract of peel showed no activity against the pathogenic bacteria tested (Table 1). Results also demonstrated that the supernatant extract of clove using $20 \%$ of methanol was active against all pathogens, higher when compared to $10 \%$ supernatant extract of clove. The largest inhibition zone was observed against $A$. hydrophila $(15.3 \pm 0.3)$, while the smallest was against $V$. harveyi $(11.0 \pm 0.6)$. Meanwhile, the $20 \%$ of methanol extract showed the largest inhibition zone against $A$. hydrophila when compared to the other pathogens. No inhibition zone was found in a control.

The MIC values for $10 \%$ and $20 \%$ of methanol clove extracts (supernatant) against the tested pathogens ranged between 0.6 and $0.8 \mathrm{mg} \mathrm{ml}^{-1}$. The $10 \%$ methanol extract showed some activities at $0.8 \mathrm{mg} \mathrm{ml}^{-1}$ against $V$. anguillarum, $V$. alginolyticus and $V$. harveyi and the extract was active against $A$. hydrophila at $0.6 \mathrm{mg} \mathrm{ml}^{-1}$. For the garlic extract on the MIC plate, there was no activity present against the pathogenic bacteria tested for concentrations above $1.0 \mathrm{mg} \mathrm{ml}^{-1}$. Overall, the findings showed that the growth of most of the tested pathogens were found to inhibit $0.6 \mathrm{mg} \mathrm{ml}^{-1}$ to $0.8 \mathrm{mg} \mathrm{ml}^{-1}$ extract. 
Table 1: Antibacterial activity of supernatant clove extract of using methanol against marine pathogens by disc-diffusion method

\begin{tabular}{|c|c|c|c|}
\hline \multirow[b]{2}{*}{ Pathogens } & \multicolumn{3}{|c|}{ Supernatant extract of clove (mm) } \\
\hline & $10 \%$ Methanol & $20 \%$ Methanol & $40 \%$ Methanol \\
\hline Aeromonas hydrophila & $15.3 \pm 0.3$ & $15.0 \pm 0.6$ & - \\
\hline Vibrio anguillarum & $11.0 \pm 0.6$ & $12.6 \pm 0.3$ & - \\
\hline Vibrio alginolyticus & $11.3 \pm 0.3$ & $13.0 \pm 0.6$ & - \\
\hline Vibrio harveyi & $11.0 \pm 0.6$ & $12.0 \pm 0.6$ & - \\
\hline
\end{tabular}

$(-)=$ No inhibition

Table 2: Minimum inhibitory concentration (MIC) and minimum bactericidal concentration (MBC) of supernatant extract of clove at $10 \%$ and $20 \%$ of methanol. Results are expressed in $\mathrm{mg} \mathrm{m}^{-1}$

\begin{tabular}{llccc}
\hline & & \multicolumn{2}{c}{ Supernatant extract of clove (mm) } & 20\% Methanol \\
\hline Pathogen & & $\mathbf{1 0 \%}$ Methanol & MBC & MIC \\
Aeromonas hydrophila & MIC & 0.8 & 0.6 & MBC \\
Vibrio anguillarum & 0.6 & 0.8 & 0.6 & 1.0 \\
Vibrio alginolyticus & 0.8 & 1.0 & 0.6 & 1.0 \\
Vibrio harveyi & 0.8 & 1.0 & 0.6 & 1.0 \\
& 0.8 & & 0.8 \\
\hline
\end{tabular}

Supernatant clove extract of $10 \%$ methanol had the MBC value of $1.0 \mathrm{mg} \mathrm{ml}^{-1}$ for $V$. alginolyticus and $V$. harveyi. At this concentration, no bacterial growth was observed. Meanwhile, the $M B C$ values for A. hydrophila and $V$. anguillarum were $0.8 \mathrm{mg} \mathrm{ml}^{-1}$. This research was further tested with $\mathrm{MBC}$ value of supernatant clove extract that was extracted with $20 \%$ of methanol. Results showed that $A$. hydrophila, $V$. anguillarum and $V$. alginolyticus were bacteriocidal at $1.0 \mathrm{mg} \mathrm{ml}^{-1}$ concentration while $V$. harveyi was bacteriocidal at of $0.8 \mathrm{mg} \mathrm{mll}^{-1}$ concentration, respectively. The results revealed that $V$. harveyi had a lower MBC value and bacteriocidal at a lower concentration of supernatant clove extract when compared to the other marine pathogens tested (Table 2).

This study was conducted to examine the ability of garlic clove and peel to inhibit the growth of marine pathogens as a natural alternative and as an antibacterial substance. This is with the purpose to substitute the use of antibiotics to treat pathogenic bacterial infections in farmed fishes. In this study, two types of solvents (methanol and water) were used for garlic extraction. Two concentrations of methanol extracts, $10 \%$ and $20 \%$ (supernatant extract of clove), showed the highest antimicrobial activities towards A. hydrophila, V. anguillarum, V. alginolyticus and $V$. harveyi when compared to the water extracts of clove and peel. In fact, the water extract of garlic showed no inhibitory effect on the pathogenic bacteria tested, both in the disc-diffusion assay and MIC assay. This is in agreement with the previous studies that reported methanol extracts of plant products had a stronger inhibition towards bacterial pathogens in vitro than aqueous ones (Parekh et al., 2005; Sheikhlar et al., 2017). It has also been reported that methanol was more effective than other solvents including hexane or ethanol (Eloff, 1998; Karaman et al., 2003). This could be due to methanol being more effective at extracting bioactive compounds with antimicrobial activity.

Several studies have provided strong evidence that most of the biological function of garlic clove is caused by active substance known as allicin (Li et al., 2007), which is the most important organosulphide present in garlic. Rattanachaikunsopon and Phumkhachorn (2007) reported that some herbal extracts produce antimicrobial effects on pathogenic bacteria by reducing the pathogenic bacteria's active compound. Another factor to the reduced efficacy of the aqueous extract may be due to the characteristic of allicin that decomposes faster (Ankri and Mirelman, 1999). Furthermore, allicin acts as an antibiotic, antidiabetic and antihypertensive (Shinkafi et al., 2013) .

On the other hand, $40 \%$ methanol supernatant clove extract was not able to inhibit the growth of all pathogens tested. This may be due to the use of methanol at high concentration which then was able to degrade the active compounds. Results clearly showed that $40 \%$ of methanol extract was incapable to interrupt the RNA production and lipid synthesis. If RNA is not hampered by allicin, protein synthesis will not be affected. Thus, it will result in the development of organism or bacteria as they get sufficient amount amino acids and proteins for their growth (Durairaj et al., 2009).

The values obtained through MIC and MBC of the methanol extracts against $A$. hydrophila, $V$. anguillarum, $V$. alginolyticus and $V$. harveyi supported the results of the discdiffusion assay. The MIC values obtained were lower when compared to the MBC values obtained in this study. This indicates that the supernatant extract of clove is bacteriocidal at a higher concentration and bacteriostatic at a lower level of concentration. 
Based on the results of this study and findings from the previous reports, it can be concluded that $A$. sativum extract of clove is capable of fulfilling all criteria of antibacterial agents. It is cheap, easy to obtain and safe to be applied. Furthermore, the supernatant methanol extract of clove showed the greatest antimicrobial activities against the tested pathogenic bacteria. Thus, supernatant extract of clove should be tested as a potential phytobiotic candidate in aquaculture that may help reduce the reliance of antibiotics. The pure compound that is responsible for the antimicrobial activity should be isolated from the raw extract of garlic, for future research. In conclusion, the supernatant extract of $A$. sativum clove should provide several advantages to prevent and/or treat bacterial diseases as a natural alternative in aquaculture.

\section{Acknowledgments}

This research was supported by Ministry of Higher Education Malaysia through Fundamental Research Grant Scheme (FRGS/2013/5524396) and Higher Institution Centre of Excellence (HiCoE) grant of Innovative Vaccine and Therapeutics against Fish Diseases, Vote No.: 6369100.

\section{References}

Alderman, D.J. and T.S. Hastings: Antiobitic use in aquaculture Development of antibiotic resistance-potential for consumer health risks. Int. J. Food Sci. Tech., 33, 139-155 (1998).

Ankri, S. and D. Mirelman: Antimicrobial properties of allicin from garlic. Microbes Infec., 1, 125-129 (1999).

Ariga, T. and T. Seki: Antithrombotic and anticancer effects of garlicderived sulfur compounds: Areview. Biofactors, 26, 93-103 (2006).

Block, E.:The Chemistry of Garlic and Onions. Scientific Amer, 252, 114119 (1985).

Bondad-Reantaso, M.G., R.P. Subasinghe, J.R. Arthur, K. Ogawa, S. Chinabut, R. Adlard, Z. Tan and M. Shariff: Disease and health management in Asian aquaculture. Veter. Parasitol., 132, 249-272 (2005).

Corzo-Martinez, M., N. Corzo and M. Villamiel: Biological properties of onions and garlic. Trend Food Sci. Technol., 18,609-625 (2007).

Cristea, V., A. Antache, J. Green, A. Docan, L. Dediu and M. Mocanu: The use of phytobiotics in aquaculture. Lucrări Stiintifice-Seria Zootechnie, 57, 250-255 (2012).
Durairaj, S., S. Srinivasan and P. Lakshmanaperumalsamy: In vitro antibacterial activity and stability of garlic extract at different $\mathrm{pH}$ and temperature. Electr. J. Biol., 5, 5-10 (2009).

Eloff, J.N.: Which extractant should be used for the screening and isolation of antimicrobial components from plants? J. Ethnopharmacol., 60, 1-8 (1998).

Hoseinifar, S.H., H.K. Zou, H.K. Miandare, H. Van Doan, N. Romano and M. Dadar: Enrichment of common carp (Cyprinus carpio) fingerlings diet with Medlar (Mespilus germanica) leaf extract: Effects on growth performance and skin mucosal immunity. Fish Shellfish Immunol, 67, 346-352 (2017).

Karaman, I., F. Sahin, M. Gulluce, H. Ogutchu, M. Sengul and A. Adiguzel: Antimicrobial activity of aqueous and methanol extracts of Juniperus oxycedrus L.J. Ethnopharmacol., 85, 231-235 (2003).

Kareem, Z.H., Y.M. Abdelhadi, A. Christianus, M. Karim and N. Romano: Effects of some dietary crude plant extracts on the growth and gonadal maturity of Nile tilapia (Oreochromis niloticus) and their resistance to Streptococcus agalactiae. Fish Physiol. Biochem., 42,757-769 (2016).

Kolkovski, S. and J. Kolkovski: Herbal Medicine in Aquaculture. Int. Aquafeed., 14, 28-31 (2011).

Li, Y., S.Y. Xu. and D.W. Sun: Preparation of garlic powder with high allicin content by using combined microwave-vacuum and vacuum drying as well as microencapsulation. J. Food Engin., 83, 76-83 (2007).

Parekh, J., D. Jadeja and S. Chanda: Efficacy of aqueous and methanol extracts of some medicinal plants for potential antibacterial activity. Turkish J. Biol., 29, 203-210 (2007).

Rattanachaikunsopon, P. and P. Phumkhachorn: Bacteriostatic effect of flavonoids isolated from leaves of Psidium guajava on fish pathogens. Fitoterapia, 78, 434-43 (2007).

Sheikhlar, A., G.Y. Meng, R. Alimon, N. Romano and M. Ebrahimi: Euphorbia hirta extract improved the resistance of Sharptooth catfish, Clarias gariepinus to Aeromonas hydrophila. J. Aqu. Anim. Hlth., 29, 225-235 (2017).

Shinkafi, S.A. and H. Dauda: Antibacterial activity of Allium cepa (Onion) on some pathogenic bacteria associated with ocular infections. $J$. Appl. Med. Sci., 1, 147-151 (2013).

Thanikachalam, K., M. Kasi and X. Rathinam: Effect of garlic peel on growth, haematological parameters and disease resistance against Aeromonas hydrophila in African catfish Clarias gariepinus (Bloch) fingerlings. Asian Pac. J. Trop. Med., 3, 614-618 (2010).

Yin, G., G. Jeney, T. Racz, P. Xu, X. Jun and Z. Jeney: Effect of two Chinese herbs (Astragalusradix and Scutellaria radix) on non specific immune response of tilapia, Oreochromis niloticus. Aquaculture, 253, 39-47 (2006). 